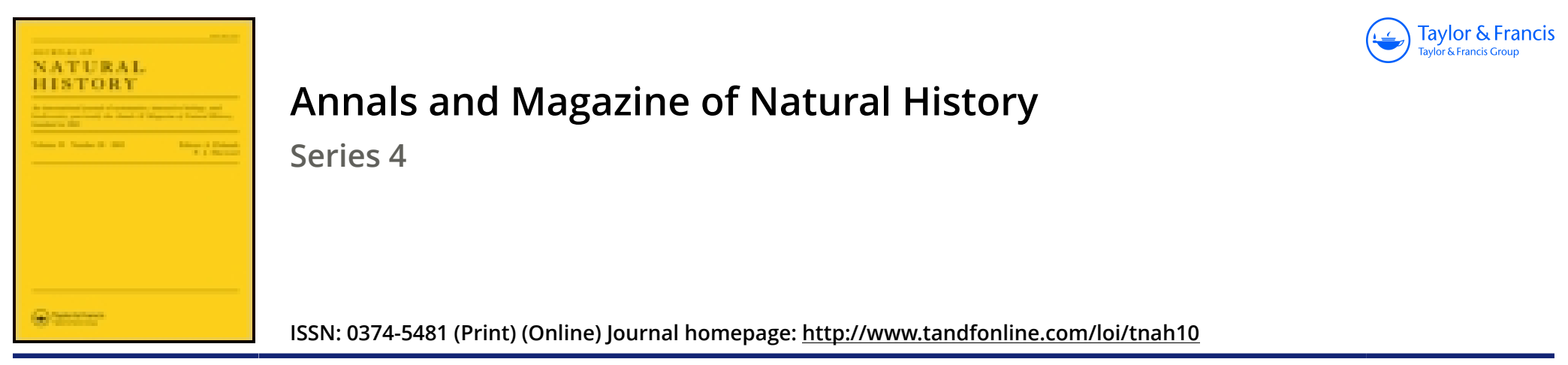

\title{
XXIII.-Third notice of a collection of fishes made by Mr. Swinhoe in China
}

Albert Günther F.R.S.

To cite this article: Albert Günther F.R.S. (1874) XXIII.-Third notice of a collection of fishes made by Mr. Swinhoe in China, Annals and Magazine of Natural History, 13:74, 154-159, DOI: 10.1080/00222937408680829

To link to this article: http://dx.doi.org/10.1080/00222937408680829

曲 Published online: 13 Oct 2009.

Submit your article to this journal $\lceil\pi$

Џ Article views: 5

Q View related articles $₫$ 
XXIII.-Third Notice of a Collection of Fishes made by Mr. Swinhoe in China. By Dr. Albert Günther, F.R.S.

Is the two previous communications on Mr. Swinhoe's collections of Chinese fishes published in this Journal for 1873 (Sept. pp. 239-250, and Nov, pp. 377-380) the majority of species enumerated were from Shanghai, and only eleven from the more northern Chefoo. A case just received from this indefatigable zoologist contained collections made exclusively in the latter locality, adding much to our knowledge of its fauna. The species of tishes collected by Mr. Swinhoe at Chefoo amount now to forty-seven.

\section{Mustelus manazo, Schleg.}

13. Triacis semifasciata, Girard.

\section{Raja porosa, sp. n.}

Allied to Raja marginata. The anterior part of the snout is abruptly contracted into a narrow thin appendage ; the width of the interorbital space is more than one third of the distance of the eye from the end of the snout. Anterior profile undulated. Teeth in fifty-four or fifty-six series in the upper jaw, pointed in the male, flat in the female (as in the majority of the species of Raja). Superciliary margin with a series of spines; rostral process with small stellate asperities; a series of three or four spines in the median line of the back behind the head; tail with three series of spines in the male and with five in the female. The width of the disk is much more than the distance from the end of the snout to the hind margin of the ventral fin. Upper parts brown, with the snout white; lower parts whitish, tinged with brown. The skin of the lower part of the snout and of the throat is perforated with numerous large pores, white in the centre and surrounded by a black ring.

The male is provided with a band of hooks near the angle of the pectoral fin and again on each side of the head, and the anterior margin of the disk is covered with asperities on its upperside in its whole length. The female is smooth on the parts just mentioned, but provided with a broad band of small hooks along the upperside of the posterior margin.

Two specimens, male and female, adult, 11 inches broad.

15. Trygon, sp., young.

16. Hapalogenys nigripinnis (Schleg.).

17. Pagrus major, Rich. 
18. Chrysophrys Swinhonis, sp. $\mathrm{n}$.

D. $\frac{11}{11}$. A. $\frac{3}{8}$. L. lat. 55 . L. transv. $6 \frac{1}{2} / 15$.

The height of the body is contained twice and two fifths in the total length (without caudal), the length of the head thrice and one fifth. Eye rather small, one half of the length of the snout, more than one half of the width of the interorbital space (which is convex), and equal to the height of the suborbital. Suborbital not quite twice as long as high. Cheek with seven series of scales. A very slight protuberance above the upper anterior angle of the eye. Molar teeth in four series above, and in three below. Dorsal spines very strong; the fourth, fifth, sixth, and seventh of nearly equal length, and half as long as the head. The second anal spine very strong; stronger, but not longer, than the dorsal spines. Caudal fin but slightly emarginate. Pectoral fin extending to the anal. Silvery; a spot at the commencement of the lateral line, the operculum, a broad margin of the vertical fins, and the membrane of the ventral fins black.

The largest of four specimens is 14 inches lang.

19. Pelor japonicum, C. \& V.

20. Seriola Lalandii, C. \& V.

21. Caranx atropus, Bl. Schn.

22. Echeneis naucrates, L.

23. Scicena Dussumieri, C. \& V.

24. Otolithus aureus, Richards. Ichth. Chin. p. 224.

D. $9 \mid \frac{1}{28} \cdot \quad$ A. $2 / 7$. L. lat. 86 .

The height of the body is contained four times and a half in the total length (without caudal), the length of the head thrice and three fourths. There are nine scales in a transverse row between the anterior dorsal spine and the lateral line. Snout obtusely conical, not much longer than the eye, with the upper jaw slightly overlapping the lower. Cleft of the mouth wide, the maxillary extending beyond the hind margin of the orbit. Eye large, its horizontal diameter being equal to one fifth of the length of the head and to the width of the interorbital space, which is somewhat convex. Canine teeth of the upper jaw rather small. Dorsal spines rather strong, the fourth being the longest and two fifths of the length of the head. Anal spine very feeble. Silvery, with bronze- 
colour tinges; hinder and upper part of the axil of the pectoral fins black.

One specimen, $22 \frac{1}{2}$ inches long.

25. Platycephalus japonicus, Tiles.

26. Platycephalus cultellatus, Richardson, Ichth. Chin. p. 217.

D. $1|7|$ 13. A. 13 . L. lat. 160 .

The length of the head is contained thrice and two fifths in the total length (without caudal); the distance between the eyes is more than one half of the length of the snout. The upper surface of the head is quite flat, the ridges being scarcely prominent. Præopercular spines strong, the upper shorter than the lower. Lateral line smooth. Grey; all the upper parts, paired fins, and dorsal rays densely dotted and punctulated with brown. Caudal fin with two oblique black bands above, with one below, and one straight band along the middle.

One specimen, 15 inches long. A second, smaller specimen was obtained at Shanghai.

This species is closely allied to $P$. insidiator, from which it will be readily distinguished by its much smaller scales. The figure on which Richardson founded this species is very rudely executed, and the ridges are represented in the form of thorns; however, the coloration shows that the artist has had before him the same species from which my notes are taken.

27. Trigla Kumu, Less.

28. Chirus hexagrammus, Pall.

29. Agrammus Schlegelii, Gthr.

30. Gobius hasta, Schleg.

31. Trionophorichthys trigonocephalus, Gill.

This species has the chest scaly. A fresh specimen from Chefoo shows the following coloration: it is dark brown, with an indistinct black longitudinal band along the middle of the side; the lower part of the head, the dorsal fins, and the caudal are punctulated or finely marbled with blackish and white.

32. Trionophorichthys taniatus, sp. n.

D. $6 \mid 12-13$. A. 12 . L. lat. 60.

About eighteen longitudinal series of scales between the second dorsal fin and the anal. The height of the body is 
two ninths of the total length (without caudal), the length of the head two sevenths. Head broader than high, flat above. The width between the orbits is less than the diameter of the eye, which is one fifth of the length of the head. Snout as long as the eye, obtuse, with the cleft of the mouth horizontal, the upper jaw being slightly longer than the lower; the maxillary extends slightly beyond the anterior margin of the orbit. The entive head and the chest before the ventrals naked. Scales etenoid. Dorsal fins nearly equally high, lower than the body; caudal obtusely rounded; the ventrals terminate at a great distance from the vent. Greyish yellow, with two brown longitudinal bands on each side-the upper starting from the superciliary margin and running along the base of the dorsal fins to the upper caudal rays, the lower from the lower part of the eye across the upper portion of the axil and along the middle of the side of the body.

'Two specimens, the larger of which is 3 inches long.

33. Sphyrana pinguis, sp. n.

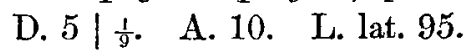

The height of the body is contained seven times in the total length (without caudal), the length of the head thrice and one fourth. Eye large, its diameter being two elevenths of the length of the head and one half of the postorbital portion. Maxillary terminating at some distance in front of the orbit. Mandible without lobe in front, armed with seven larger teeth on each side, the smaller teeth not included. Interorbital space rather convex, narrower than the orbit. Præoperculum with the angle produced into a rounded lobe. The origin of the first dorsal fin corresponds to the extremity of the pectoral, and is behind the root of the ventral fin. The distance between the first and second dorsals is less than twice the length of the latter. Above greenish, beneath silvery. Fins light-coloured.

This species has a remarkably round body. Two specimens, 14 inches long.

\section{Mugil soiuy, Basil.}

35. Ditrema Temminckii, Blkr.

36. Pleuronectes asperrimus, Schleg.

37. Pleuronectes variegatus, Schleg.

38. Synaptura zebra, B1.

39. Exoccetus brachycephalus, Gthr. Ann. \& Mag. N. Hist. Ser. 4. Vol. xiii. 
40. Belone anastomella, C. \& V.

41. Saurida tumbil, Bl.

42. Engraulis encrasicholus, L.

The common anchovy of Europe.

43. Engraulis chefuensis, sp. n.

D. 13-14. A. 31. L. lat. 35.

Allied to Engraulis rhinorhynchus.

The height of the body equals the length of the head, and is one fourth of the total (without caudal). Snout much pointed, and much projecting beyond the lower jaw. Teeth present in both jaws, minute. Maxillary somewhat dilated above the mandibulary joint, tapering behind, not reaching the gill-opening. Gill-rakers fine, closely set, as long as the eye. Origin of the dorsal fin rather nearer to the end of the snout than to the root of the caudal fin. Anal fin commencing at a short distance behind the last dorsal rays. Abdomen compressed, the spiny scutes extending forwards to the gillopening. A blackish spot across the neck.

Several specimens, 5 inches long.

\section{Pellona elongata, Benn.}

45. Chatoëssus punctatus, Schleg.

46. Muroenesox cinereus, Forsk.

47. Monacanthus septentrionalis, sp. $\mathrm{n}$.

D. 38-39. A. 34-35.

Skin rough, velvety. The height of the body is one half of the total length (without caudal). Pectoral fin opposite to the hind margin of the orbit, immediately behind the base of the dorsal spine. Snout with the upper profile scarcely convex. Dorsal spine two thirds or three fourths as long as the head, compressed and armed with a single lateral series of small barbs; side of the tail without any armature. Dorsal and anal fins low. Ventral spine fixed. Uniform brownish grey. Caudal blackish, with the interradial membrane whitish, and without any cross bands.

Two specimens, 11 inches long.

There is a small specimen $4 \frac{1}{2}$ inches long in the collection, which I believe to be the young of this species, but which differs in a remarkable manner by having the dorsal spine subtetrahedral, a row of barbs running along each edge. 
The anterior barbs are much smaller and much closer together than the posterior. The upper half of the body shows two or three irregular longitudinal bands.

I may add here that Mr. Swinhoe has quite recently obtained at Shanghai specimens of Carcharias lamia (Risso), a species hitherto believed to be limited to the Atlantic, and of a sturgeon which appears to be the

\section{Acipenser Dabryanus.}

Acipenser Dabryanus, Duméril, Nouv. Arch. Mus. iv. p. 98, pl. 22. fig. 1.

One specimen, 31 inches long. The numbers of shields differ a little from those given by Duméril. Dorsal 12; lateral 34 or 37 ; ventral 11 ; D. 51 .

XXIV.-On the Dwarf Buffalo of Pennant. By Sir Victor Brooke, Bart., F.Z.S.

To the Editors of the Annals and Magazine of Natural History.

Gentremen,

With reference to Dr. Gray's remarks upon my paper on "African Buffaloes" in the December number of your Journal (p. 499), I would merely ask any person interested in the matter to turn to Pennant's 'Synopsis of Quadrupeds' and to judge for himself as to the correctness of Dr. Gray's statements. Pennant, in his description of the "Dwarf" (p. 9), thus writes, "The horns of this animal are in the Museum of the Royal Society, described by Grew, page 26," and upon plate 8 . figure 3 he figures these horns.

Turton, having founded the name Bos pumilus upon Pennant's "Dwarf," it follows that the horns spoken of and figured by Pennant are typical specimens of "Bos pumitus."

In the British Museum are a pair of horns, entered in the 'Hand-list of Edentate, Thick-skinned, and Ruminant Mammals' $(1873$, p. 82$)$ as received from the Museum of the Royal Society, which exactly agree with Pennant's description and figure. There can therefore, I think, be no reasonable doubt that they are the identical specimens figured and described by Pennant.

These horns are likewise the type of Blyth's Bubalus reclinis. 